AFRREV VOL 10 (2) APRIL, 2016 | 16

African Research Review

An International Multi-disciplinary Journal, Ethiopia

Vol. 10(2), Serial No.41, April, 2016: 16-30

ISSN 1994-9057 (Print)

ISSN 2070-0083 (Online)

Doi: http://dx.doi.org/10.4314/afrrev.v10i2.2

\title{
Regional International Organizations as Conflict Managers: The Limits and Capabilities
}

\section{Enuka, Chuka}

Department of History and International Studies, Nnamdi Azikiwe University, Awka, Nigeria

Phone Number: +2347067307867

E-mail: chukaenuka@yahoo.com

\&

\section{Nwagbo, Samuel}

Department of Political Science

Nnamdi Azikiwe University, Awka

Anambra State, Nigeria

\begin{abstract}
There has been, especially since the end of the cold war, greater emphasis on the roles of regional international organizations in conflict management. With the increased spate of armed conflicts over the past two decades, demand for conflict management has consequentially increased. Though interstate wars evidently declined since the post-cold war, but intrastate wars and civil conflicts
\end{abstract}


AFRREV VOL 10 (2) APRIL, 2016 | 17

have increased both in number and variety. Beyond traditional civil wars, the international system has experienced a relatively new phenomenon in form of failed or disrupted states. Such also foster instability in regions as well as carrying a human toll that often exceed that from civil wars. Global organizations have been overburdened with these challenges, resulting in limited attention to some areas as well as donor fatigue. The UN and leading states have seemingly ignored certain civil wars and failed states. This leaves gap that has assumed the concern of regional organizations, many of which cannot afford to ignore the conflict and civil wars at their doorsteps. How well conflict matters have been handled in conflict-torn zones by regional organizations has been a concern in the International Relation scholarship. Therefore, to probe the capabilities and effectiveness of regional international organizations in conflict management, and the challenges that assail their new roles as conflict managers in the international system, forms the concern of this paper.

\section{Introduction}

The regionalization of peace and conflict management is a global trend that takes its legal departure from the charter framework of the United Nations. Article 52 empowers regional organizations through regional actions to deal with matters relating to the maintenance of regional international peace and securities, provided that such actions are consistent with the purposes and principles of the United Nations. Article 53(1) clearly states that "the Security Council shall, where appropriate, utilize such regional arrangements or agencies for enforcement action under its authority..." though these and other relevant articles of the United Nations explicitly recognizes the roles of regional organizations in peace maintenance and conflict management, yet some inherent limitations are obvious. First, regional organizations are confined to geographically narrow disputes, as opposed to those with broader scope and potential impact. Second, regional organizations are clearly to be subordinate to the United Nations Security Council, which retains supervisory authority over regional actions as well as the right to supersede regional efforts if necessary. For much of the cold war era, regional organizations performed those limited roles in conflict management. But with the end of the cold war, regional organizations have assumed increasingly varied, and in some cases primary roles in conflict management. As Diehl (2008:538) capture it, "from the late 
AFRREV VOL 10 (2) APRIL, 2016 | 18

1980s and early 1990s to the present time, there has been a dramatic upsurge in regional conflict management activities of all forms". There are a number of reasons for greater emphasis on conflict management by regional international organizations. Most obvious is that the demand for conflict management has increased as well, evidenced by an increase in armed conflicts over the past two decades (Hensel 2002). As a result, United Nations peacekeeping and humanitarian intervention grew dramatically both quantitatively and qualitatively (Kabia 2009). The period between 1989 and 1996 alone witnessed the establishment of 29 peacekeeping operations, with a sharp rise in the annual budget of peacekeeping from 230 million US dollars in 1988 to 3.6 billon US dollars in 1995 (Michel and Doyle 1998). The increased number of missions and expanded role however overstretched the capacity of the United Nations and posed complications in terms of logistics, inter-force relations, communications, financial resources and chain command. The result has been a string of failures and humiliation of United Nations force in places such as Somalia, Rwanda and Bosnia. Consequently, the United Nations was forced to scale down its intervention in intra-state conflicts in the mid-1990s. This led to the emergence of assertive regional organizations and sub-regional bodies willing to take up the task of filling that gap by intervening in such countries where and when conflict conditions call for action. The aim of this paper is to explore the possibilities and capabilities of regional international organizations in conflict management, and to x-ray the challenges that assail their new roles as conflict managers in the international system.

\section{Regional Organizations and Conflict Management}

Conflict management encompasses a range of actions, all designed to promote the prevention, mitigation, and ultimately resolution of conflict. One can conceive of a continuum of conflict management activities that vary according to the level of commitment required and the operational level of the activity (Cox and Jacobson 1971). At the lower end of the continuum, regional organizations create norms on a variety of subjects, several of which may promote peace and security in the region. For example, there is a strong norm of democratization in the Western Hemisphere, fostered by the Organization of American States (OAS) (Dexter 2002). This norm not only discourages extraconstitutional regime change, which could promote regional instability, but also promotes peaceful conflict management indirectly, given that democratic states 
are less likely to fight one another and more likely to adopt peaceful dispute resolution mechanisms (Russett 1994). More directly, regional organizations pass normative resolutions or issue statements on particular threats to regional order. The Association of Southeast Asian Nations (ASEAN) issued a declaration in 1992 calling for the peaceful resolution of disputes surrounding the Spratly Islands and the South China Sea. More specific to a given event, the North Atlantic Treaty Organization (NATO) issued a declaration on terrorism following the Madrid train bombings in 2004 (Crocker 2008). Such actions serve to promote the interests of a region's members broadly and consequently are not necessarily expected to have an immediate impact. In contrast, other normative actions are designed to promote immediate changes in behaviour by member states. For example, following a military coup in Ecuador in 2000, the OAS passed resolutions denouncing this action and called for the restoration of the democratically elected president (Cooper and Legler 2001).

Moving along a continuum indicating greater commitment and more operational activities, regional organizations undertake a variety of diplomatic efforts to advance peace and security. Diplomatic efforts, such as mediation, assume that conflicts cannot ultimately be managed or resolved except by the disputants themselves. Diplomatic efforts are able to achieve conflict management in a number of different ways, most notably by bringing the parties in dispute together when they otherwise might not negotiate with one another. Political pressure and the prospect of legitimacy and prestige are elements that allow the regional organization to bring warring parties to the bargaining table. Regional organizations and their representatives may also play an active role in the negotiations themselves. They may clarify the positions of the parties, redefine the issues, serve as conduits for negotiation, pressure each side to make concessions, and formulate alternative proposals (Hopmann 1996). Regional organizations may also play a role in providing additional incentives for the parties to come to an agreement, such as economic or political aid. Regional groups or their members might also offer themselves as guarantors of any conflict management agreement, undertaking an ongoing role in the implementation of the peace agreement.

There are several conditions under which regional organizations develop norms and promote cooperation. One is in response to ongoing crises and war. The European Union 
AFRREV VOL 10 (2) APRIL, 2016 | 20

(EU) was among the first actors to respond to the internationalized civil war in Bosnia, dispatching a peace mission led by former NATO secretarygeneral Lord Carrington. Similarly, the Southern African Development Community (SADC) was instrumental in the negotiations of the 1999 Lusaka Accords dealing with the war in the Democratic Republic of the Congo (formerly Zaire) (Zartman 2007). Regional organizations also respond to longterm threats to peace and security sometimes by constructing norms on weapons or by facilitating arms control cooperation. For example, the Arms Control and Regional Security (ACRS) initiative in the Middle East was an effort (though a failed one) to achieve arms control in that region. Finally, some regions have moved beyond traditional security concerns to emerging topics on the security agenda, with the goal of establishing joint rules and norms. Such concerns include drug trafficking, terrorism, and human security problems, with Latin American organizations being the most involved in these areas.

Moving towards the other end of the continuum, regional organizations also participate in a range of activities that fall under the peacekeeping rubric. Traditional peacekeeping refers to the deployment of lightly armed troops in response to threats to regional security or in response to ongoing wars (Diehl 2008). Peacekeeping may entail a variety of functions, including cease-fire monitoring, humanitarian assistance, post conflict reconstruction, and arms control verification. The deployment of the ECOWAS Monitoring Group into Liberia in 1990, offers a good example of peacekeeping roles by a regional international organization. Regional organizations might also promote conflict resolution and democratic institutions in ethnically divided states. The most coercive set of options, requiring the greatest political and resource commitment can be categorized as enforcement. Traditionally, enforcement refers to large scale military operation designed to defend the victims of aggression and restore peace and security by the defeat of aggressor forces. Enforcement may also be designed to impose a particular solution in a given conflict (Lepgold and Weiss 1998). This strategy relies on the deterrence value of collective military action. If deterrence fails, however, states need to carry out the threatened military action and restore peace and security in the region. A recent example of this is NATO's actions against the former Yugoslavia in Kosovo. Enforcement actions may be roughly subdivided into two types. The first is collective security, in which a coalition of states, generally acting through an international organization, seeks to deter or defeat any coalition member that uses military 
AFRREV VOL 10 (2) APRIL, 2016 | 21

force to alter the status quo. A second type is what has been referred to as collective defence. This also involves deterrence or military action against an aggressor but is more often the product of a traditional military alliance rather than an international governmental organization. The original role of the NATO alliance in Europe is the prototypical example.

\section{Capabilities of Regional International Organizations in Conflict Management}

The capability of the regional international organizations in conflict management can be better appreciated when viewed and premised in the context of comparative weighing of their advantages over global international organizations. On the overall, regional organizations may not overtly be said to have record of performance superior to that of the United Nations in conflict management, nevertheless, there are differences between the two kinds of organizations in conflict handlings. Although one might expect regional conflict management efforts to experience success and failure for many of the same reasons as UN efforts, the former may have some unique advantages, including greater consensus in the organization, greater support from the disputants, heightened chances for conflict resolution, and more control over third-party states.

Greater Consensus in the Organization: One might expect regional organizations to have an advantage over the United Nations because their membership is more homogenous (Bennett 1991). States in a regional organization are more likely to be at the same development level; share historical, ethnic or tribal roots; and have similar political outlooks stemming from facing common regional problems. These commonalities are supposed to provide greater consensus among the members and make authorization of conflict management easier, as there will be fewer disagreements blocking strong action. Regional organizations are also not constrained, as is the United Nations, by the veto power of leading members. Indeed, some regional organizations have adopted procedures to avoid such deadlock.

Greater Support from the Disputants: A second possible advantage for regional organizations is the support given them by the disputants and the local population will be greater than for comparable UN efforts. This argument relies on the notion that the people and governments in a region have a natural affinity 
AFRREV VOL 10 (2) APRIL, 2016 | 22

with those in that geographic area and an inherent suspicion of what they perceive as outside intervention. Thus, there are frequently calls for regional (Arab, African etc.) solutions to regional conflicts before international forces intervene. Disputants may be more accepting of actions by a regional organization, but just as important, substantial groups and others in the conflicting states may see such actions as more legitimate. To the extent that regional actions can generate more support than global organizations like the United Nations missions, they have an important advantage.

Heightened Chances for Conflict Resolution: Regional efforts may also be better at promoting conflict resolution than is the United Nations, which has tended to respond to crises with Band-Aid solutions to security problems, with limited follow-up diplomatic efforts. The United Nations has often helped negotiate cease-fire and /or deployed peaceful troops prior to conflict resolution, but it has not often facilitated a final peace settlement once those peacekeepers are in place. The net effect is that the international community and the protagonists themselves may be discouraged from pursuing further diplomacy to resolve the disputes and from reaching a settlement, if negotiations do occur (Diehl 2008). At best the United Nations has waited until a settlement was reached to deploy peacekeepers and carry out peace-building activities, but such a settlement may never occur or take place too late to save hundreds or thousands of lives. Regional organizations may be more concerned with resolving the underlying conflict because the implications are much greater for the states in the area. Furthermore, they may more closely tie passing resolutions and the stationing of peacekeeping troops to a mechanism such as negotiations, or to an actual settlement plan, such as elections for resolving the dispute. In this way, there is hope that regional organizations can not only promote conflict management, but facilitate final conflict resolution as well.

A final possible advantage of regional conflict management efforts is that they may be better able to secure the support of the interested third party states, who will almost certainly participate in the debate and authorization of any action, whereas they may not in a United Nations forum. Interested third parties are those that border the affected area and/or have significant economic and security interests in the conflict. In this way, the third party state has a better chance of modifying the operation according to its views and more likely to support it. More important, it is less likely to sabotage the organization's efforts, 
AFRREV VOL 10 (2) APRIL, 2016 | 23

a major cause of the failure of UN peacekeeping operations and economic sanctions.

\section{Constraints On Regional Organizations' Conflict Management Capabilities}

In spite of their demonstrable capabilities in conflict management, regional organizations do face situational constraints when dealing with external threats to regional peace and the involvement of regional powers. A consistent theme in the analysis of regional organizations is their inability to concerted action against their most powerful members (Bryon 1984). Regional operations are unlikely to be authorized in conflicts that directly involve the global powers or regional powers. The organization has neither the political clout nor the resources to mount an operation opposed or not actively supported by those states. A regionally powerful state would be able to resist pressure to support any action, and even where one is authorized, the hegemon could effectively sabotage the mission through direct action or covertly through intermediate actors. This condition necessarily confines strong regional responses to conflicts between or within smaller states. The problem of dealing with a hegemon is most evident in the Western Hemisphere. The Organization of American States (OAS) has been unable to mount any effective operational action that is not supported by the United States. Although the United Nations might also face difficulties in gaining United States cooperation in Panama, for example, the possibility seems foreclosed in the case of the OAS. Other regions may have fewer problems, at least given current power configurations. Any regional arrangement in Asia would have difficulty restraining Chinese or Japanese behaviour. Similarly, a variety of regional and sub regional organizations in the southern part of Africa may not compel South Africa to halt any transgression it might commit. In general, only the United Nations offers the potential to restrain a regional power. The United Nations has the resources, even without the cooperation of some states, and it has the political power to pressure states to accede to its peacekeeping operations. The inability to restrain regional hegemons is a major disadvantage to regional initiatives.

Another constraint and incapacitation of regional organization in conflict management is with respect to ethnic conflict and weak states. These problems have been prevalent in Africa (Diehl 2008). The reason that ethnic conflicts and weak states are key problems for regional conflict management is 
AFRREV VOL 10 (2) APRIL, 2016 | 24

that these conflicts have significant negative externalities. Historically, internal conflicts were not considered to be in the purview of regional organization but rather were something to be dealt with solely by the state itself. This represented a hard shell view of sovereignty. Many members of the African Union have objected to any military intervention in Darfur, Sudan, on sovereignty grounds. At the same time, ethnic conflicts and weak states have contributed to greater prospects for intervention by neighbouring states, independent of regional organizations. The Congo conflict was the most egregious case of direct intervention in a civil war. There, a number of neighbouring states sent troops to fight for and against various Congolese factions (Zartman 2007). This made it made almost impossible for a regional organization to reach consensus on taking action.

Another problematic threat to regional peace and security comes from territorial disputes in which states fight over the possession of a piece of land, usually geographically contiguous to both sides. Especially dangerous are those disputes that involve territory that is valued for its intangible rather than tangible qualities; that is religious, ethnic, and historical claims to a territory make it more difficult to find a compromise positions than do those territorial disputes over resource or defence concerns (Hensel 2002). Africa still suffers from the results of the 1885 Berlin Conference, in which its colonial borders were drawn without reference to historical delineation or the groups living within various territories. This has been somewhat mitigated however, by the agreement among African leaders around the time of independence that state borders would not be altered by military force. Though most border issues may have been settled especially in Europe, but many more have proved intractable for many regional institutions in Africa and Asia.

Related to the kinds of threat that a region faces is the presence of internal rivalries between its members. Such rivalries not only may present conflicts that are difficult to manage but also may paralyze attempts at collective action by a regional association. Regional wars and other serious threats to peace seem to coalesce around these rivalries (Diehl 2000). Such conflicts often labelled enduring rivalries are the greatest threat to peace. A comparison between Europe and Asia reveals how rivalries affect regional conflict management efforts. ASEAN+3 states (ten Southeast Asian members plus China, Japan, and South Korea) are involved in well over twenty rivalries, with 
AFRREV VOL 10 (2) APRIL, 2016 | 25

a number of patterns relevant for regional conflict management. First, several of the rivalries reflect a common external enemy, i.e. North Korea. Nevertheless, a closer inspection reveals that although China, Japan and South Korea share some interests with respect with North Korea, their preferences and policies with respect to that country are by no means convergent. Furthermore, each of those three states has rivalries with the other two. Thus, although some cooperation with respect to foreign policy might be forthcoming, there is certainly not a broad basis for regional cooperation centred on North Korea. The lack of a common external enemy has long been a limiting factor in furthering Asian security cooperation (Foot 1995). Second, and related to the previous point, eleven of the rivalries are more likely to fight one another than an external enemy (Diehl 2000). Most notable are the rivalries between three of the largest economic forces in the grouping: China, Japan and South Korea (the +3 states). Indeed, the presumed leading states in the coalition, China, Japan, are involved in eleven rivalries, including against each other (Diehl 2008). Yet there are several crosscutting rivalries as well, most critically the disagreement over the Spratly Islands, which involves China, the Philippines, Malaysia, Vietnam, and Brunei. Until the major-power rivalries and to a lesser extent the controversy surrounding the Spratly Islands are resolved, there will be limits to how far the ASEAN+3 states can cooperate on regional security matters.

The ability of regional organizations to play significant roles in conflict management is largely conditioned by the authority and mandate granted to them by their members. In some cases, no security institution at all exists in a region. For example, the north Asian region has no regional organization to handle conflict management (Hemmer and Katzenstein 2002). In other parts of Asia, the institutions are relatively weak. The South Asian Association for Regional Cooperation (SAARC) provides for cooperation only in the social and economic issue areas. By definition then, it is unable to exercise any significant role in the Indo-Pakistan conflict, except very indirectly and then only through a functionalist approach to peace (Diehl 2008). Other regional organizations such as ASEAN are similarly handicapped by limited mandates for security action. ASEAN action in particular has been limited to normative declarations. ASEAN has taken some recent steps to clarify its decision rules, but the organization has not committed itself to use of military force and has reaffirmed its principle of non-interference in the internal affairs of members. In other regions, the mandates of regional organizations and the level of 
AFRREV VOL 10 (2) APRIL, 2016 | 26

institutionalization vary widely. Until recently, the African Union was structurally weak, often little more than a forum for yearly meetings of heads of state on that continent. Much of this may be a backlash against United Nations involvement in Congo during the 1960s and a preference for non-intervention of any variety by outside actors. Indeed, the predecessor OAU prohibited alliances among its members, effectively foreclosing collective security options. Accordingly, to the extent that it was involved in peace-making activities, the organization operated through ad hoc committees. The AU has expanded its activities to include election monitoring and peacekeeping. It also made provisions in 2005 for a nonaggression and common defence agreement, although it is not clear that this addresses some of the main security threats there, including civil war and failed states.

Several regional organizations have the legal provisions to undertake a variety of different kinds of actions. The Organization of American States has collective security provisions contained in its charter, precisely the Article 28, as well as provisions for other kinds of actions, although most of these are directed against extra-regional threats or interstate aggression, rather than being internal matters. Some regional entities also contain conflict management provisions, even if their primary purposes are in the economic realm. Several regional trade associations in Africa include mechanisms for conflict management when disputes arise over resources. ECOWAS for instance, has since the post-cold war era shifted remarkably from being an entirely and purely economic outfit. It now demonstrates political and strategic concerns. The organization has since then, assumed the role of a regional conflict manager, an assignment which was not originally assigned to it by the charter which established it. SADC is also caught in the trap of function-shift as it tries to grapple with post-cold war conflict realities. At the other end of the continuum is the European region, which has multiple institutions for dealing with security. These have overlapping memberships and complementary roles. Of longest standing import is NATO, which traditionally handled the duties for collective security and collective defence. Since the end of the Cold War, its missions have been modified and it functioned as a peacekeeper in Bosnia and Afghanistan. The European Union has extended its authority in the security realm with a common defence policy and various diplomatic initiatives. NATO and the European Union are supplemented by the West European Union (WEU) and the 
AFRREV VOL 10 (2) APRIL, 2016 | 27

Organization for Security and Cooperation in Europe, the latter of which has been involved in ethnic conflicts and election supervision.

Besides the limiting factors of authority and mandate, lack of requisite resources does also impede regional organizations' conflict management activity. Resources in this context refers to the financial, political, and in some cases military/logistical capacity to take action. Organizations are not inherently endowed with such capacities but must rely on members for their provision for operational activities. The alternative is that conflict management actions will be confined to normative and diplomatic initiatives, which require few tangible resources. Some operations, specifically peacekeeping, collective security, and humanitarian assistance, require large amounts of money to pay for supplies and personnel. A number of regional organizations like SADC are composed of less developed states that lack the capacity for adequately constructing such operations, much less sustaining them. Increasingly, such organizations have appealed for support (financial, logistical, training etc.) from the United Nations, NGOs, or leading states in the world system to carry out missions; to a limited extent, this has mitigated some of the problems encountered. This may be more common in the future as global actors subcontract activities they are unwilling to perform to regional organizations and others (Weiss 1997). The presence of financial resources alone is not a guarantee of effectiveness for a regional organization. The organization and its members must also have political capital to influence regional activities. There is little doubt that the Gulf Cooperation Council (GCC), made up of six oil-rich Arab states, has the financial resources to fund almost any operation, but its members (except Saudi Arabia), are weak politically and militarily and are unable to broadly affect policy in the Middle East (Miller 2008). Military resources are the third component distinguishing effective regional organizations from their less effective counterparts everywhere. NATO clearly has the military training, logistics, and personnel to carry out a broad range of operations, even beyond the immediate European theatre. Other regional organizations must draw on poorly trained and equipped military personnel from their member states, and those militaries often lack long-force projection capabilities.

\section{Conclusion}

There are a number of reasons for emphasis on conflict management at the regional level. Most obvious is that the demand for conflict management has 
AFRREV VOL 10 (2) APRIL, 2016 | 28

increased as well, evidenced by an increase in armed conflicts over the past two decades. The end of the Cold War was far from being the end of wars. It in fact marked the beginning of wars, new type of wars that shifted dramatically from inter-state to being more of intra-state. Since the era, the international system has seen an increase in the number of civil wars, with significant negative externalities, including genocidal incidences and refugees streaming across borders. Beyond traditional civil wars, the world has also experienced a relatively new phenomenon manifesting in areas of failed states or disrupted states, which in their manifestations, foster instability in regions as well as carrying a human toll that often exceed that from civil wars. As these conflicts and violent eruptions surge, global organizations and their members become overburdened with the challenges, resulting in limited attention to some areas as well as donor fatigue. The United Nations and leading states have also chosen to ignore certain wars or failed states. The resultant effect is that some states which became enmeshed in conflict mess are faced with the threat and possibility of getting exterminated from the political map of their regions. This leaves gaps that have been filled by regional organizations, many of which cannot afford to ignore the conflicts and problems at their doorsteps. Yet, in this new assumed role of conflict management, the regional organizations efforts are not without hurdles and limitations. There have been the challenging issues of taming and restraining regional powers, internal rivalries within the membership of the organization, mandate and authority given to the organization by its members, the debilitating matters of resources, all of which constitutes an obstacle, though not an insurmountable one, that frustrates the conflict management potentials of regional organizations. Should these identified problems be dealt with by the regional bodies, the chances abound for their better roles in conflict handlings, given especially the indubitable advantages they have over global organizations: 
AFRREV VOL 10 (2) APRIL, 2016 | 29

\section{References}

Bennett, L. (1991). International organizations: Principles and issues, Englewood Cliffs: Prentice-Hall.

Bryon, J. (1984). Regional security in Latin America and Africa: The OAS and OAU in light of contemporary security issues. PSIS Occasional Papers1/84, Geneva: Graduate School of International Studies.

Cooper, A. \& Legler, T. (2001). The OAS democratic solidarity paradigm: Questions of collective and national leadership. Latin American Politics and Society, Volume 43, pp.103-126.

Cox, R. \& Jacobson, H. (1971). The anatomy of influence. New Heaven: Yale University Press.

Crocker, C. (2008). Leashing the dogs of war: Conflict management in a divided world. Washington D.C: United States Institute of Peace Press.

Diehl, P. (2008). Regional organizations and conflict management in the postcold war era. Brown Journal of World Affairs, Vol.12, No. 2, pp.191202.

Foot. R. (1995). Pacific Asia: The Development of Regional Dialogue. In Louise Fawcett (ed.) Regionalism in world politics. Oxford: Oxford University Press.

Hensell, P. (2002). Recognizing and responding to trends in armed conflict. Conflict Management and Peace Science, Volume 19, pp.27-52.

Hemmer, C. \& Katzenstein, P. (2002). Why is there no NATO in Asia? Collective identity, regionalism, and the origins of multilateralism. International Organization, 56: 575-607.

Hopmann, T. (1996). The negotiation process and the resolution of international conflicts. Columbia: University of South Carolina Press.

Kabia, J. (2009). Humanitarian Intervention and conflict resolution in West Africa: From ECOMOG to ECOMIL. England: Ashgate.

Lepgold, J. \& Weiss, T. (eds) (1998). Collective conflict management and changing world politics. Albany: State University of New York Press. 
AFRREV VOL 10 (2) APRIL, 2016 | 30

Miller, B. (2008). Conflict management in the Middle East: Between the old and the new. Regional Conflict Management and Peace Science, Vol. 25 , No. 10 , pp.51-90

Russet, B. (1994). Grasping the democratic peace. Princeton: Princeton University Press.

Weiss, T. (2008). Beyond UN subcontracting: Task-sharing with regional security arrangement and service-providing NGOs. New York: St. Martin's Press.

Zartman, W. (2007). Regional conflict management in Africa. Journal of Conflict Studies, Vol. 10, No6, pp.21-46. 